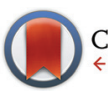

CrossMark click for updates

Cite this: Org. Biomol. Chem., 2015, 13,7664

Received 7th May 2015,

Accepted 8th June 2015

DOI: $10.1039 / c 5 o b 00926 j$

www.rsc.org/obc

\title{
A divergent approach to benzylisoquinoline-type and oxoaporphine alkaloids via regioselective direct ring metalation of alkoxy isoquinolines $\uparrow$
}

\author{
Benedikt Melzer and Franz Bracher* \\ Methoxy- and benzyloxy-substituted isoquinolines are regioselectively metalated at C-1 with the \\ Knochel-Hauser base, subsequent trapping with aromatic aldehydes gives aryl(isoquinolin-1-yl)carbinols \\ as building blocks for divergent syntheses of different types of benzylisoquinoline alkaloids. Photochemi- \\ cal cyclization of ortho-bromo analogues under reductive conditions gives oxoaporphine alkaloids. Nine \\ benzylisoquinoline alkaloids and two oxoaporphine alkaloids were obtained in two or three steps from \\ appropriate isoquinolines.
}

\section{Introduction}

Benzylisoquinoline alkaloids are a large group of plant secondary metabolites which includes about 2500 known structures. Besides simple benzylisoquinolines, more complex tetracyclic ring systems (aporphines, protoberberines, cularines, pavines) and the pentacyclic morphinane-type alkaloids belong to this class. All these alkaloids share a common biosynthetic origin, with $(S)$-norcoclaurine, a metabolite formed by condensation of dopamine and 4-hydroxyphenylacetaldehyde, as the first common intermediate. Manifold biological activities have been reported for alkaloids from this class, among them narcotic, spasmolytic, dopaminergic, ion-channel modulating, and cytotoxic properties. A timely review of structures, biosynthesis and pharmacology of benzylisoquinoline alkaloids is provided by Hagel and Facchini. ${ }^{1}$

Benzylisoquinoline alkaloids in the narrower sense bear up to three oxygen functions (hydroxy, methoxy, methylenedioxy) on the carbocyclic part of the isoquinoline, and one or more oxygen functions at the benzylic ring; the benzylic carbon is a methylene group in most cases, but can also be a carbinol (or its methyl ether) or a carbonyl group (Fig. 1).

Classical synthetic approaches to the benzylisoquinoline alkaloids are inspired by the biosynthesis and include acidmediated cyclizations of arylacetamides (Bischler-Napieralski) or arylacetaldimines of phenylethylamines (Pictet-Spengler), followed by a dehydrogenation step. ${ }^{2}$ Alternatively, isoquino-

Department of Pharmacy - Center for Drug Research, Ludwig-Maximilians University, Butenandtstr. 5-13, D-81377 Munich, Germany.

E-mail: Franz.Bracher@cup.uni-muenchen.de; Fax: +49-89-2180-77802;

Tel: $+49-89-2180-77301$

$\dagger$ Electronic supplementary information (ESI) available. See DOI: 10.1039/ c5ob00926j
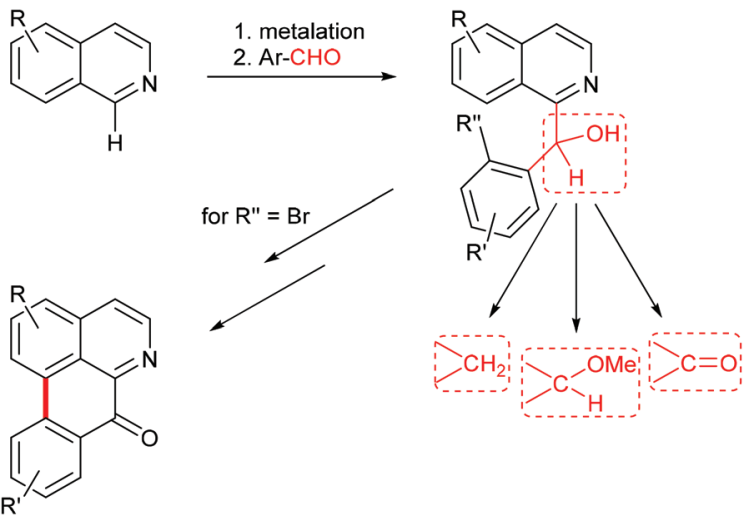

Fig. 1 New approach to benzylisoquinoline and oxoaporphine alkaloids via regioselective metalation of substituted isoquinolines.

lines can be benzylated at C-1 via $N$-benzoyl-1,2-dihydroisoquinoline-1-carbonitriles (Reissert synthesis ${ }^{3}$ ), but this method suffers from the need to use stoichiometric amounts of toxic cyanide. For the preparation of alkaloids containing a C-1 substituent other than methylene, laborious variants of these methodologies must be applied. ${ }^{4-9}$ A Pomeranz-Fritsch approach to benzylisoquinolines through cyclization of complex 2-aryl arylethylaminoacetaldehyde acetals was found to have a very narrow scope. ${ }^{10,11}$ A convenient access to 1-benzoylisoquinolines has been developed recently, utilizing direct acylation of isoquinolines at C-1 with benzoyl radicals. ${ }^{12,13}$ Other approaches start from 1-iodoisoquinolines, and consist of either nucleophilic substitution with deprotonated arylacetonitriles, followed by oxidation, ${ }^{14}$ or zinc insertion followed by copper-catalyzed coupling with an aroyl chloride. ${ }^{15}$ 


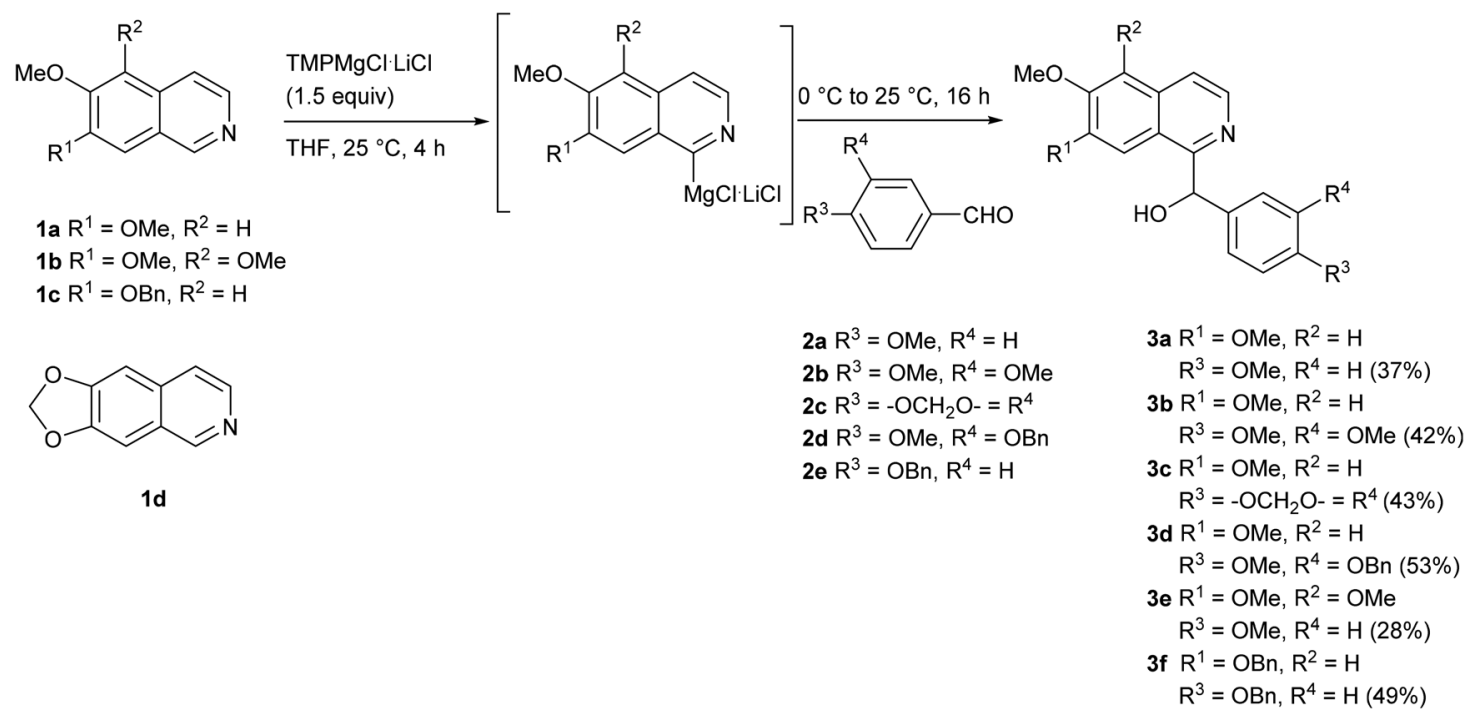

Scheme 1 Synthesis of secondary alcohols 3 from alkoxy-substituted isoquinolines 1.

In continuation of our recent work on the synthesis of aromatic alkaloids using direct ring metalations of heterocycles as the crucial step,${ }^{16,17}$ we intended to work out a novel, flexible approach to benzylisoquinoline alkaloids. This work was inspired by two single reports of Knochel on the direct metalation of isoquinoline ${ }^{18}$ and 6,7-dimethoxyisoquinoline ${ }^{19}$ at C-1 with the hindered amide base TMPMgCl-LiCl. Quenching with iodine, followed by Pd-catalyzed Negishi cross-coupling of the 1-iodoisoquinoline with a benzylzinc reagent gave the benzylisoquinoline alkaloid papaverine (9), whereas attempted direct cross-coupling of the magnesiated isoquinoline with a benzyl chloride did not provide the alkaloid. ${ }^{19}$ We envisaged to trap 1-magnesiated isoquinoline building blocks with appropriately substituted benzaldehydes to obtain aryl(isoquinolin-1-yl)methanols, which in turn would open an access to benzylisoquinolines, benzoylisoquinolines, and 1'-methoxy-substituted benzylisoquinolines in one single step (hydrogenolysis of the benzylic hydroxy group, oxidation, or etherification) each. This should represent a divergent approach to four common subtypes of benzylisoquinoline alkaloids. Further, carbinols prepared from ortho-bromo-substituted benzaldehydes should open an access to oxoaporphine alkaloids via intramolecular biaryl synthesis, utilizing either photochemical, ${ }^{14,20-22}$ radical $^{23}$ or Pd-catalyzed ${ }^{24,25}$ reactions. The oxoaporphines are of high pharmaceutical relevance due to their antibacterial, antifungal, anticancer and other biological activities ${ }^{26,27}$ (Fig. 1).

\section{Results and discussion}

We started our investigations with 6,7-dimethoxyisoquinoline (1a), since the metalation at C-1 with the Knochel-Hauser base (TMPMgCl-LiCl) had been reported previously by the Knochel group. ${ }^{19}$ Metalation with 1.5 equivalents of the base over $4 \mathrm{~h}$ at room temperature, followed by reaction with various benzaldehydes 2 (1.5 equiv.) at $0{ }^{\circ} \mathrm{C}$ gave the expected racemic secondary alcohols $3 a-d$ in moderate yields (37-53\%) (Scheme 1). One of these alcohols (3b) is the racemate of the alkaloid papaverinol (isolated from Papaver somniferum and other plants; previously synthesized by either oxidation of papaverine $(9)^{28}$ or reduction of papaveraldine $(\mathbf{4})^{29}$ ), alcohol $3 \mathrm{a}$ is the dimethyl ether of the alkaloid annocherin A (7). ${ }^{30}$ Side-reactions were not observed, and significant amounts (up to $49 \%$ ) of the starting material 1a were recovered. Modifications of the reaction conditions were examined in order to improve the yields. The use of just 1.1 equivalents of TMPMgCl-LiCl led to lower yields of the secondary alcohols. However, the use of 2.0 equivalents TMPMgCl$\cdot \mathrm{LiCl}$ did not increase the yields. Also longer reaction times for the metalation step up to $16 \mathrm{~h}$ did not result in higher yields. Attempted metalation with the "frustrated Lewis pair" TMPMgCl$\cdot \mathrm{BF}_{3} \cdot \mathrm{LiCl}$, a system which was applied to the regioselective metalation of pyridines and quinolines before, ${ }^{31}$ failed completely due to spontaneous formation of a precipitate.

In order to explore the scope of this methodology, especially with view on alkaloids with other substitution patterns in the isoquinoline part, we expanded our method to the metalation of readily available isoquinolines $\mathbf{1 b}-\mathbf{d}^{32-34}$ (Scheme 1). The metalation of 5,6,7-trimethoxyisoquinoline (1b) with $\mathrm{TMPMgCl} \cdot \mathrm{LiCl}$ (1.5 equiv.) at room temperature for $4 \mathrm{~h}$, followed by reaction with 4-methoxybenzaldehyde (2a) afforded the secondary alcohol $3 \mathbf{e}$ in $28 \%$ yield. The direct metalation of 7-benzyloxy-6-methoxyisoquinoline (1c) under the same reaction conditions and reaction with 4-(benzyloxy)benzaldeyhde (2e) provided the secondary alcohol 3 f in $49 \%$ yield. Unfortunately, any attempts to perform a controlled ring metalation of 6,7-methylenedioxyisoquinoline (1d) failed. An 
iodine quenching after a metalation experiment gave a poorly separable mixture of iodinated products, from which $<10 \%$ of impure 8-iodo derivative was isolated. We further investigated whether better yields can be obtained by activation of the aromatic aldehydes with a Lewis acid $\left(\mathrm{BF}_{3}\right)$, but independent of the sequence of addition of the components spontaneous precipitation was observed, and not even traces of the desired carbinols were obtained.

Having the carbinols 3a-f in hand, divergent syntheses were accomplished, leading to benzylisoquinoline alkaloids bearing other functional groups at the benzylic $\mathrm{C}-1^{\prime}$ position.

Oxidation of the secondary alcohols $\mathbf{3 b}$ and $3 \mathbf{e}$ with manganese(Iv) oxide in refluxing dichloromethane for $6 \mathrm{~h}$ afforded the natural products papaveraldine (4; isolated from Papaver somniferum and other plants; first total synthesis by oxidation of papaverine $\left.(9)^{35}\right)$ in $68 \%$ and thalimicrinone $(5$; isolated from Thalictrum minus var. microphyllum; ${ }^{36}$ first total synthesis utilizing a Reissert-type reaction ${ }^{5}$ ) in $98 \%$ yield, respectively (Scheme 2).

Deprotonation of the secondary alcohols $\mathbf{3 b}$ and $\mathbf{3} \mathbf{c}$ using sodium hydride in dry DMF and subsequent reaction with iodomethane over $2 \mathrm{~h}$ furnished the racemic $O$-methylated alkaloids setigerine (6a; isolated from Papaver setigerum $D C ;^{37}$ first total synthesis from papaverinol (3b), see ref. 38) and setigeridine (6b; isolated from Papaver setigerum $D C ;{ }^{37}$ first total synthesis see ref. 9) in yields of $77 \%$ and $91 \%$, respectively. Analogous $O$-methylation of $\mathbf{3} \mathbf{f}$ under the same conditions led to $\mathbf{6 c}$, the central intermediate in the synthesis of annocherin B (8), in 90\% yield (Scheme 3).

By hydrogenolytic removal of both $O$-benzyl protective groups in $3 \mathrm{f}$ and $\mathbf{6 c}$ in methanol over $\mathrm{Pd} / \mathrm{C}$ catalyst (room temperature for $24 \mathrm{~h}, 90$ and $66 \%$ yields) the first total syntheses of the racemic alkaloids annocherin A (7) and annocherin B (8; both isolated from Annona cherimola ${ }^{39}$ ) were completed. The preparation of 7 was accomplished in just two steps (overall yield 44\%) starting from 7-benzyloxy-6-methoxyisoquinoline (1c), annocherin B (8) was synthesised in three steps with an overall yield of $29 \%$ (Scheme 4 ).

Deoxygenation of the benzhydrol-type alcohol papaverinol (3b) was found to be less feasible, and needed careful optimi-
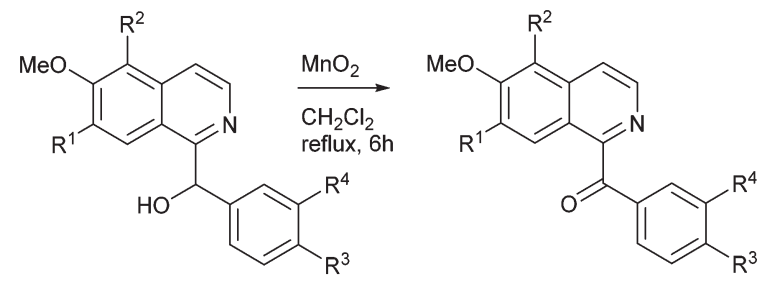

$$
\begin{aligned}
\text { 3b } \mathrm{R}^{1} & =\mathrm{OMe}, \mathrm{R}^{2}=\mathrm{H} \\
\mathrm{R}^{3} & =\mathrm{OMe}, \mathrm{R}^{4}=\mathrm{OMe} \\
3 e \mathrm{R}^{1} & =\mathrm{OMe}, \mathrm{R}^{2}=\mathrm{OMe} \\
\mathrm{R}^{3} & =\mathrm{OMe}, \mathrm{R}^{4}=\mathrm{H}
\end{aligned}
$$

$$
\begin{aligned}
4 \mathrm{R}^{1} & =\mathrm{OMe}, \mathrm{R}^{2}=\mathrm{H} \\
\mathrm{R}^{3} & =\mathrm{OMe}, \mathrm{R}^{4}=\mathrm{OMe}(68 \%) \\
5 \mathrm{R}^{1} & =\mathrm{OMe}, \mathrm{R}^{2}=\mathrm{OMe} \\
\mathrm{R}^{3} & =\mathrm{OMe}, \mathrm{R}^{4}=\mathrm{H}(98 \%)
\end{aligned}
$$

Scheme 2 Synthesis of the benzoylisoquinoline alkaloids papaveraldine (4) and thalimicrinone (5).<smiles>[R]c1ccc(C(O)c2nccc3c([R])c(OC)c([R])cc23)cc1[R]</smiles><smiles>[R]c1ccc(C(OC)c2nccc3c([R])c(OC)c([R])cc23)cc1[R]</smiles>

$$
\begin{aligned}
3 b R^{1} & =O M e, R^{2}=H \\
R^{3} & =O M e, R^{4}=O M e \\
3 c R^{1} & =O M e, R^{2}=O M e \\
R^{3} & =-O_{2} O-=R^{4} \\
3 f R^{1} & =O B n, R^{2}=H \\
R^{3} & =O B n, R^{4}=H
\end{aligned}
$$

$$
\begin{aligned}
6 a R^{1} & =O M e, R^{2}=H \\
R^{3} & =O M e, R^{4}=O M e(77 \%) \\
6 b R^{1} & =O M e, R^{2}=O M e \\
R^{3} & =-O_{2} O-=R^{4}(91 \%) \\
6 c R^{1} & =O B n, R^{2}=H \\
\mathrm{R}^{3} & =O B n, R^{4}=H(90 \%)
\end{aligned}
$$

Scheme 3 O-Methylation of the alcohols $3 b, c, f$ to setigerine (6a), setigeridine $(6 \mathrm{~b})$, and $6 \mathrm{c}$.

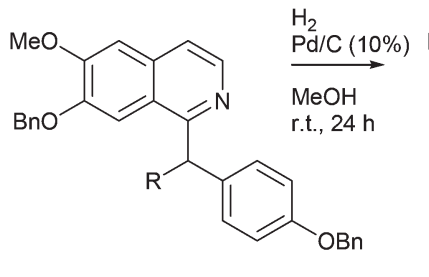

3f $\mathrm{R}=\mathrm{OH}$ $6 \mathrm{c} R=\mathrm{OMe}$

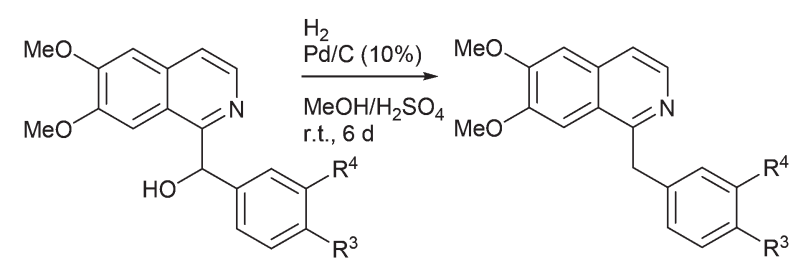

3b $\mathrm{R}^{3}=\mathrm{OMe}, \mathrm{R}^{4}=\mathrm{OMe}$ $3 d R^{3}=O M e, R^{4}=O B n$
$9 \mathrm{R}^{3}=\mathrm{OMe}, \mathrm{R}^{4}=\mathrm{OMe}(60 \%)$ $10 \mathrm{R}^{3}=\mathrm{OMe}, \mathrm{R}^{4}=\mathrm{OH}(75 \%)$
Scheme 4 Synthesis of the alkaloids annocherin A (7), annocherin B (8), papaverine (9), and palaudine (10) by multiple hydrogeneolyses.

zation of the reaction conditions. Finally, we found that hydrogenation over $\mathrm{Pd} / \mathrm{C}(10 \%)$ in a methanol/sulphuric acid mixture at room temperature for $6 \mathrm{~d}$ gives the benzylisoquinoline alkaloid papaverine (9; isolated from Papaver somniferum and other plants; first total synthesis by Pictet and Gams ${ }^{40}$ ) in $60 \%$ yield. It was also possible to simultaneously remove the $O$-benzyl protective group and deoxygenate the benzylic position of compound $\mathbf{3 d}$ under these conditions to yield the alkaloid palaudine (10; isolated from Papaver somniferum; ${ }^{41}$ first total synthesis by $O$-demethylation of papaverine ${ }^{42}$ ) in $75 \%$ yield (Scheme 4).

Having established a general access to variously substituted benzylisoquinolines, we wished to extend this methodology to the total synthesis of oxoaporphine alkaloids. As mentioned in the introduction (Fig. 1), intermediates bearing ortho-bromobenzyl residues can be applied to intramolecular aryl-aryl 
coupling reactions, and on the basis of literature data the photochemical approach appeared most promising. Formally, the pertinent 1-(2-bromobenzoyl)isoquinolines appear to be the best substrates, but previous investigations revealed that the corresponding carbinols are much more susceptible to this cyclization, an oxidation of the carbinol to the keto group obviously takes place after completed cyclization under the workup conditions. ${ }^{20-22}$ Chuang et al. ${ }^{14}$ even reported a "reductive photocyclization" of 1-(2-bromobenzoyl)isoquinolines to oxoaporphines, comprising an in situ reduction of the starting ketones to the carbinols, followed by photocyclization and aerial re-oxidation during workup. These insights made our above-mentioned approach highly attractive, since it provides a direct access to the carbinols as the most promising cyclization substrates.

Fortunately, the ring metalation/aldehyde quenching protocol could be applied to ortho-bromobenzaldehydes without any problems. Reaction of C-1 magnesiated 6,7-dimethoxyisoquinoline with 2-bromobenzaldeyhde (11a) furnished carbinol 12a in 69\% yield, with 6-bromovertraldehyde (11b) the carbinol 12b was obtained in $35 \%$ yield. A first attempt of a photocyclization of 12a in methanol (concentration $2.5 \mathrm{mM}$ ) in a photoreactor (mercury vapour lamp, $125 \mathrm{~W}, 3 \mathrm{~h}$ ) gave the expected oxoaporphine alkaloid lysicamine (13; isolated from Lysichiton camtschatcense Schott var. japonicum Makino; ${ }^{43}$ first total synthesis starting from nuciferine ${ }^{44}$ ) in only $10 \%$ yield, accompanied by numerous by-products. Longer reaction times led to even more by-products. However, photocyclization in the presence of $\mathrm{NaBH}_{4}$ (1.5 equivalents) proceeded well and provided lysicamine (13) in 53\% yield after $3 \mathrm{~h}$ reaction time. Obviously, it is suitable not only to use the carbinol as a starting material, but also to suppress the formation of keto forms of educt and product during the irradiation process, and then rely on spontaneous oxidation during workup. Photo-induced cyclization of alcohol 12b under the same conditions yielded the oxoaporphine alkaloid oxoglaucine (14; isolated from Liriodendron tulipifera, L. ${ }^{45}$ first total synthesis utilizing a Pschorr cyclization starting from nitropapaveraldine ${ }^{46}$ ) in $59 \%$ in just $1 \mathrm{~h}$ (Scheme 5).

In conclusion, we worked out a new protocol for the synthesis of aryl(isoquinolin-1-yl)carbinols by direct regioselective metalation of alkoxy isoquinolines, followed by reaction with aromatic aldehydes. These carbinols are versatile intermediates for divergent syntheses of benzylisoquinoline alkaloids and oxoaporphines. Eleven alkaloids were synthesized using this protocol in two (for 1'-methoxy compounds three) steps starting from readily accessible 1-unsubstituted alkoxy isoquinolines.

\section{Experimental section}

\section{General information}

All reactions were performed under nitrogen atmosphere with flame-dried glassware, unless otherwise stated. Solvents used were of HPLC grade or p.a. grade and/or purified according to

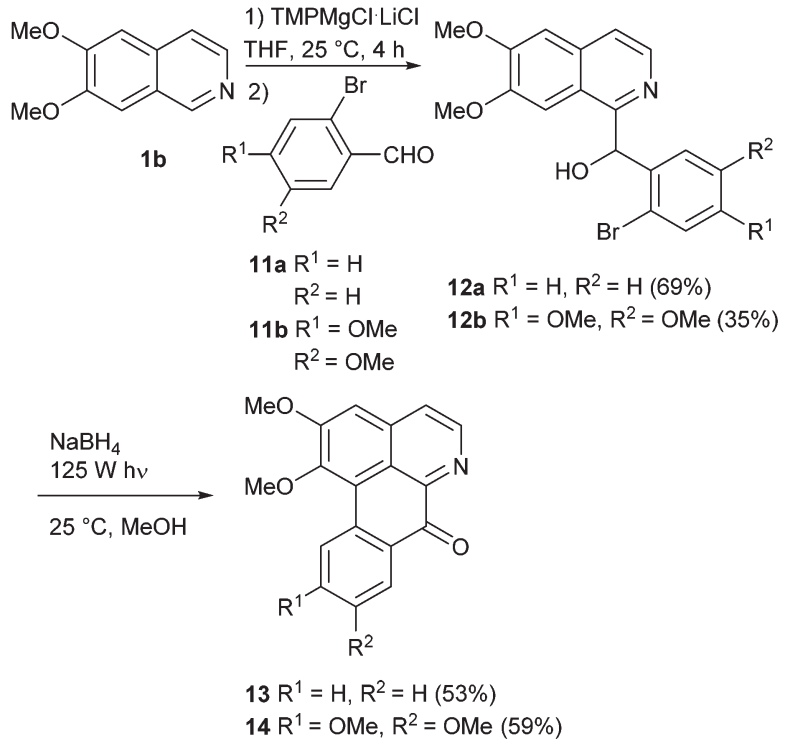

Scheme 5 Synthesis of the oxoaporphine alkaloids lysicamine (13) and oxoglaucine (14).

standard procedures. Photochemical reactions were conducted using a HPK 125W high pressure mercury vapor lamp from Heraeus Noblelight. Melting points were determined by open tube capillary method with a Büchi melting point B-450 apparatus. IR measurements were carried out with a Perkin-Elmer FTIR Paragon 1000 spectrometer. NMR spectra were recorded with Jeol J NMR GX (400 or $500 \mathrm{MHz}$ ) and Avance III HD Bruker BioSpin (400 or $500 \mathrm{MHz}$ ) spectrometers with residual non-deuterated solvent as internal standard. Spectra were recorded in deuterated solvents and chemical shifts are reported in parts per million ( $\mathrm{ppm}) . J$ values are given in Hertz. Multiplicities are abbreviated as follows: $\mathrm{s}=$ singlet, $\mathrm{d}=$ doublet, $\mathrm{t}=$ triplet, $\mathrm{m}=$ multiplet. Signal assignments were carried out based on ${ }^{1} \mathrm{H},{ }^{13} \mathrm{C}, \mathrm{HMBC}, \mathrm{HMQC}$ and COSY spectra. NMR spectra were analyzed with the NMR software MestReNova, Version 5.1.1-3092 (Mestrelab Research S.L.) HRMS were performed by electron impact (EI) at $70 \mathrm{eV}$ with a Thermo Finnigan MAT 95 or a Jeol GCmate II spectrometer or by electrospray ionization (ESI) with a Thermo Finnigan LTQ FT Ultra Fourier Transform Ion Cyclotron resonance mass spectrometer. Chromatographic purification of products was performed by using flash column chromatography on Merck silica gel $60(0.015-0.040 \mathrm{~mm})$ as stationary phase.

\section{General procedure A (preparation of secondary alcohols 3a-f/12a-b)}

A dry and nitrogen flushed $25 \mathrm{~mL}$ Schlenk tube, equipped with a magnetic stirring bar, was charged with the appopriate isoquinoline 1a,b $(1.00 \mathrm{mmol})$ in THF $(4 \mathrm{~mL})$ or $1 \mathbf{c}(2.00 \mathrm{mmol})$ in dry THF (6 mL). TMPMgCl.LiCl (1.50 equiv., 1.0 M in THF/ toluene) was added to this solution dropwise over $2 \mathrm{~min}$. The reaction mixture was stirred at room temperature for $4 \mathrm{~h}$. After cooling to $0{ }^{\circ} \mathrm{C}$ the corresponding benzaldehyde $\mathbf{2 a - e / 1 1 a - b}$ 
(1.50 equiv.), dissolved in dry THF ( $2 \mathrm{~mL}$ ), was added dropwise to the reation mixture. The mixture was allowed to warm to room temperature within $16 \mathrm{~h}$. Then the mixture was quenched with satd. aqueous $\mathrm{NH}_{4} \mathrm{Cl}$ solution $(4 \mathrm{~mL})$ and extracted with dichloromethane $(3 \times 20 \mathrm{~mL})$. The combined organic layers were dried with $\mathrm{Na}_{2} \mathrm{SO}_{4}$ and concentrated under reduced pressure. The residue was purified by flash column chromatography.

\section{General procedure B (oxidation of secondary alcohols)}

To a solution of the appropriate secondary alcohol $3 \mathbf{b} / \mathbf{3 e}$ in dichloromethane $(3 \mathrm{~mL})$ was added manganese(Iv) oxide (10 equiv.). The resulting suspension was heated to reflux for $6 \mathrm{~h}$. After cooling to room temperature, the mixture was filtered through a pad of celite, and the celite was washed with dichloromethane $(20 \mathrm{~mL})$. The combined organic layers were concentrated under reduced pressure. The residue was purified by flash column chromatography.

\section{General procedure C (methylation of secondary alcohols)}

To a suspension of sodium hydride (1.5 equiv., $60 \%$ in mineral oil) in dry DMF (1-2 mL) was added a solution of the appropriate secondary alcohol $\mathbf{3 b} / \mathbf{3 c} / \mathbf{3 f}$ (1.0 equiv.) in dry DMF (1-2 $\mathrm{mL})$. The reaction mixture was stirred under nitrogen atmosphere at room temperature for $30 \mathrm{~min}$, before iodomethane (3.0 equiv.) was added. Stirring was continued for $2 \mathrm{~h}$ and then water $(15 \mathrm{~mL})$ was added to the mixture. The reaction mixture was extracted with dichloromethane $(3 \times 20 \mathrm{~mL})$. The combined organic layers were washed with brine $(2 \times 20 \mathrm{~mL})$, dried with $\mathrm{Na}_{2} \mathrm{SO}_{4}$ and concentrated under reduced pressure. The residue was purified by flash column chromatography.

\section{General procedure D (hydrogenolysis of diaryl methanols)}

To a solution of $\mathbf{3 b} / \mathbf{3 d}$ in $\mathrm{MeOH}(2-10 \mathrm{~mL})$ was added conc. $\mathrm{H}_{2} \mathrm{SO}_{4}(0.1-0.5 \mathrm{~mL})$ and $10 \% \mathrm{Pd} / \mathrm{C}(0.070 \mathrm{~g}-0.100 \mathrm{~g})$. The mixture was stirred under hydrogen atmosphere at room temperature for $6 \mathrm{~d}$. Then the catalyst was filtered off through a pad of celite and the resulting solution was concentrated under reduced pressure. Satd. aqueous $\mathrm{NaHCO}_{3}$ solution $(20 \mathrm{~mL})$ was added to the residue, followed by extraction with dichloromethane $(3 \times 20 \mathrm{~mL})$. The combined organic layers were dried with $\mathrm{Na}_{2} \mathrm{SO}_{4}$ and concentrated under reduced pressure. The residue was purified by flash column chromatography.

\section{General procedure E (Hydrogenolysis of benzyl ethers)}

To a solution of $3 \mathbf{f} / 3 \mathbf{c}$ in $\mathrm{MeOH}(10 \mathrm{~mL})$ was added $10 \% \mathrm{Pd} / \mathrm{C}$ $(0.100 \mathrm{~g})$. The mixture was stirred under hydrogen atmosphere at room temperature for $24 \mathrm{~h}$. Then the catalyst was filtered off through a pad of celite and the resulting solution was concentrated under reduced pressure. The residue was purified by flash column chromatography.

\section{General procedure F (Photocyclization to give oxoaporphines)}

A stirred solution of $\mathrm{NaBH}_{4}(0.019 \mathrm{~g}, 0.500 \mathrm{mmol})$ and the secondary alcohol 12a $(0.124 \mathrm{~g}, 0.330 \mathrm{mmol})$ in $\mathrm{MeOH}(132 \mathrm{~mL})$ or $12 \mathrm{~b}(0.130 \mathrm{~g}, 0.300 \mathrm{mmol})$ in $\mathrm{MeOH}(120 \mathrm{~mL})$ was irradiated in a photo reactor equipped with a medium pressure mercury vapor lamp $(125 \mathrm{~W})$ at room temperature for the indicated time. The solvent was then evaporated and the residue was dissolved in dichloromethane $(200 \mathrm{~mL})$. The solution was washed with water $(3 \times 50 \mathrm{~mL})$, the organic layer was dried with $\mathrm{Na}_{2} \mathrm{SO}_{4}$ and concentrated under reduced pressure. The residue was purified by flash column chromatography (dichloromethane/methanol $=97: 3)$.

( \pm )-(6,7-Dimethoxyisoquinolin-1-yl)(4-methoxyphenyl)methanol (3a). This compound was prepared following general procedure A fom 6,7-dimethoxyisoquinoline (1a, $0.189 \mathrm{~g}$, $1.00 \mathrm{mmol})$ with TMPMgCl$\cdot \mathrm{LiCl}(1.0 \mathrm{M}$ in THF/toluene; $1.5 \mathrm{~mL}, 1.50 \mathrm{mmol}$ ) and 4-methoxybenzaldehyde (2a, $0.204 \mathrm{~g}$, $1.50 \mathrm{mmol}$ ). The crude residue was purified by flash column chromatography (ethyl acetate/dichloromethane $=2: 1+2 \%$ triethylamine) to give $3 \mathrm{a}(0.119 \mathrm{~g}, 37 \%)$ as a pale yellow solid. mp 143-146 ${ }^{\circ} \mathrm{C} ;{ }^{1} \mathrm{H}$ NMR $\left(400 \mathrm{MHz}, \mathrm{CDCl}_{3}\right): \delta(\mathrm{ppm})=8.40(\mathrm{~d}$, $J=5.6 \mathrm{~Hz}, 1 \mathrm{H}), 7.50(\mathrm{~d}, J=5.6 \mathrm{~Hz}, 1 \mathrm{H}), 7.26(\mathrm{~d}, J=8.7 \mathrm{~Hz}, 2 \mathrm{H})$, 7.07 (s, 1H), $7.06(\mathrm{~s}, 1 \mathrm{H}), 6.82(\mathrm{~d}, J=8.7 \mathrm{~Hz}, 2 \mathrm{H}), 6.39(\mathrm{br} \mathrm{s}$, $1 \mathrm{H}), 6.15(\mathrm{~s}, 1 \mathrm{H}), 3.98(\mathrm{~s}, 3 \mathrm{H}), 3.80(\mathrm{~s}, 3 \mathrm{H}), 3.75(\mathrm{~s}, 3 \mathrm{H}) ;{ }^{13} \mathrm{C}$ NMR $\left(101 \mathrm{MHz}, \mathrm{CDCl}_{3}\right): \delta(\mathrm{ppm})=159.3,156.9,152.8,149.9$, 139.0, 136.1, 133.7, 129.1 (2C), 121.0, 119.9, 114.3 (2C), 105.4, 103.4, 72.4, 56.2, 56.0, 55.4; HRMS (ESI): $m / z(\%)=326.1390$ $[\mathrm{M}+\mathrm{H}]^{+}$(calcd for $\mathrm{C}_{19} \mathrm{H}_{19} \mathrm{NO}_{4}$ : 325.1314); IR (KBr pellet): $\nu$ $\left(\mathrm{cm}^{-1}\right)=2935,1829,1621,1567,1504,1487,1435,1418,1252$, 1202, 1160, 1101, 1039.

( \pm )-(6,7-Dimethoxyisoquinolin-1-yl)(3,4-dimethoxyphenyl)methanol (3b, racemic Papaverinol). This compound was prepared following general procedure A fom 6,7-dimethoxyisoquinoline (1a, $0.189 \mathrm{~g}, 1.00 \mathrm{mmol})$ with TMPMgCl.LiCl $(1.0 \mathrm{M}$ in THF/toluene; $1.5 \mathrm{~mL}, 1.50 \mathrm{mmol}$ ) and 3,4-dimethoxybenzaldehyde (2b, $0.249 \mathrm{~g}, 1.50 \mathrm{mmol}$ ). The crude residue was purified by flash column chromatography (ethyl acetate/ dichloromethane $=2: 1+2 \%$ triethylamine) to give $3 \mathbf{b}$ (0.150 g, 42\%) as a yellow solid. mp 135-137 ${ }^{\circ} \mathrm{C} ;{ }^{1} \mathrm{H}$ NMR $\left(500 \mathrm{MHz}, \mathrm{CDCl}_{3}\right): \delta(\mathrm{ppm})=8.36(\mathrm{~d}, J=5.6 \mathrm{~Hz}, 1 \mathrm{H}), 7.47(\mathrm{~d}$, $J=5.6 \mathrm{~Hz}, 1 \mathrm{H}), 7.08(\mathrm{~s}, 1 \mathrm{H}), 7.03(\mathrm{~s}, 1 \mathrm{H}), 6.89(\mathrm{dd}, J=8.2,2.0$ $\mathrm{Hz}, 1 \mathrm{H}), 6.79$ (d, $J=2.0 \mathrm{~Hz}, 1 \mathrm{H}), 6.76(\mathrm{~d}, J=8.2 \mathrm{~Hz}, 1 \mathrm{H}), 6.42$ (br s, 1H), $6.11(\mathrm{~s}, 1 \mathrm{H}), 3.95(\mathrm{~s}, 3 \mathrm{H}), 3.79(\mathrm{~s}, 3 \mathrm{H}), 3.78(\mathrm{~s}, 3 \mathrm{H})$, $3.73(\mathrm{~s}, 3 \mathrm{H}) ;{ }^{13} \mathrm{C} \mathrm{NMR}\left(101 \mathrm{MHz}, \mathrm{CDCl}_{3}: \delta(\mathrm{ppm})=156.7\right.$, $152.8,150.0$, 149.5, 148.9, 139.0, 136.4, 133.7, 121.1, 120.3, 119.9, 111.1, 110.8, 105.4, 103.4, 72.7, 56.2, 56.0, 56.0, 55.9; HRMS (ESI): $m / z(\%)=356.1491[\mathrm{M}+\mathrm{H}]^{+}$(calcd for $\mathrm{C}_{20} \mathrm{H}_{21} \mathrm{NO}_{5}$ : 355.1420); IR (KBr pellet): $\nu\left(\mathrm{cm}^{-1}\right)=3342,2941$, 2839, 1620, 1593, 1569, 1513, 1472, 1454, 1403, 1273, 1257, 1237, 1161, 1135, 1065, 1021.

( \pm -Benzo[ $d][1,3]$ dioxol-5-yl(6,7-dimethoxyisoquinolin-1-yl)methanol (3c). This compound was prepared following general procedure A fom 6,7-dimethoxyisoquinoline (1a, $0.189 \mathrm{~g}, 1.00 \mathrm{mmol})$ with TMPMgCl$\cdot \mathrm{LiCl}(1.0 \mathrm{M}$ in THF/ toluene; $1.5 \mathrm{~mL}, 1.50 \mathrm{mmol}$ ) and piperonal (2c, $0.224 \mathrm{~g}$, $1.50 \mathrm{mmol}$ ). The crude residue was purified by flash column chromatography (ethyl acetate/dichloromethane $=2: 1+2 \%$ triethylamine $)$ to give $3 \mathrm{c}(0.144 \mathrm{~g}, 43 \%)$ as a yellow solid. $\mathrm{mp}$ 74-76 ${ }^{\circ} \mathrm{C} ;{ }^{1} \mathrm{H}$ NMR $\left(400 \mathrm{MHz}, \mathrm{CDCl}_{3}\right): \delta(\mathrm{ppm})=8.38(\mathrm{~d}, J=5.6$ Hz, 1H), 7.49 (d, J = 5.6 Hz, 1H), 7.09 (s, 1H), 7.05 (s, 1H), 6.94 
$(\mathrm{dd}, J=7.9,1.7 \mathrm{~Hz}, 1 \mathrm{H}), 6.74(\mathrm{~d}, J=7.9 \mathrm{~Hz}, 1 \mathrm{H}), 6.64(\mathrm{~d}, J=$ $1.7 \mathrm{~Hz}, 1 \mathrm{H}$ ), 6.41 (br s, 1H), 6.10 (s, 1H), 5.87 (d, $J=1.4 \mathrm{~Hz}$, $1 \mathrm{H}), 5.84(\mathrm{~d}, 3.98 \mathrm{~J}=1.4 \mathrm{~Hz}, 1 \mathrm{H}), 3.98(\mathrm{~s}, 3 \mathrm{H}), 3.81(\mathrm{~s}, 3 \mathrm{H}) ;{ }^{13} \mathrm{C}$ NMR (101 MHz, $\left.\mathrm{CDCl}_{3}\right): \delta(\mathrm{ppm})=156.5,152.8,150.0,148.2$, $147.4,139.0,137.8,133.6,121.6,121.0,119.9$, 108.2, 107.9, 105.4, 103.3, 101.1, 72.6, 56.1, 56.0; HRMS (ESI): $\mathrm{m} / \mathrm{z}(\%)=$ 340.1179 $[\mathrm{M}+\mathrm{H}]^{+}$(calcd for $\mathrm{C}_{19} \mathrm{H}_{17} \mathrm{NO}_{5}$ : 339.1107); IR ( $\mathrm{KBr}$ pellet): $\nu\left(\mathrm{cm}^{-1}\right)=3331,3011,2902,1622,1571,1509,1486$, 1273, 1237, 1160, 1038, 976, 859.

( \pm )-(3-(Benzyloxy)-4-methoxyphenyl)(6,7-dimethoxyisoquinolin-1-yl)methanol (3d). This compound was prepared following general procedure A fom 6,7-dimethoxyisoquinoline (1a, $0.378 \mathrm{~g}, 2.00 \mathrm{mmol})$ with TMPMgCl$\cdot \mathrm{LiCl}(1.0 \mathrm{M}$ in THF/ toluene; $3.0 \mathrm{~mL}, 3.00 \mathrm{mmol}$ ) and 3-(benzyloxy)-4-methoxybenzaldehyde (2d, $0.727 \mathrm{~g}, 3.00 \mathrm{mmol}$ ). The crude residue was purified by flash column chromatography (ethyl acetate/iso-hexane $=3: 1+2 \%$ triethylamine $)$ to give $3 \mathbf{d}(0.460 \mathrm{~g}, 53 \%)$ as a pale yellow solid. mp 137-138 ${ }^{\circ} \mathrm{C} ;{ }^{1} \mathrm{H}$ NMR (500 $\mathrm{MHz}, \mathrm{CDCl}_{3}$ ): $\delta(\mathrm{ppm})=8.30(\mathrm{~d}, J=5.6 \mathrm{~Hz}, 1 \mathrm{H}), 7.41(\mathrm{~d}, J=5.6 \mathrm{~Hz}, 1 \mathrm{H})$, $7.22-7.13(\mathrm{~m}, 5 \mathrm{H}), 6.97(\mathrm{~s}, 1 \mathrm{H}), 6.90(\mathrm{~s}, 1 \mathrm{H}), 6.85(\mathrm{dd}, J=8.2$, $2.0 \mathrm{~Hz}, 1 \mathrm{H}), 6.74(\mathrm{~d}, J=8.2 \mathrm{~Hz}, 1 \mathrm{H}), 6.72(\mathrm{~d}, J=2.0 \mathrm{~Hz}, 1 \mathrm{H})$, 6.25 (br s, 1H), $6.00(\mathrm{~s}, 1 \mathrm{H}), 4.96(\mathrm{~d}, J=12.3 \mathrm{~Hz}, 1 \mathrm{H}), 4.90$ (d, $J=12.3 \mathrm{~Hz}, 1 \mathrm{H}), 3.91(\mathrm{~s}, 3 \mathrm{H}), 3.75(\mathrm{~s}, 3 \mathrm{H}), 3.62(\mathrm{~s}, 3 \mathrm{H}) ;{ }^{13} \mathrm{C}$ NMR $\left(126 \mathrm{MHz}, \mathrm{CDCl}_{3}\right): \delta(\mathrm{ppm})=156.6,152.7,149.9,149.6$, 148.5, 139.0, 137.0, 136.3, 133.6, 128.5 (2C), 127.8, 127.4 (2C), 121.0, 120.9, 119.9, 113.7, 111.8, 105.3, 103.3, 72.6, 71.1, 56.1 (2C), 55.9; HRMS (ESI): $m / z(\%)=432.1805[\mathrm{M}+\mathrm{H}]^{+}$(calcd for $\mathrm{C}_{26} \mathrm{H}_{25} \mathrm{NO}_{5}$ : 431.1733); IR (KBr pellet): $\nu\left(\mathrm{cm}^{-1}\right)=3317,2951$, 2835, 1510, 1403, 1395, 1263, 1236, 1156, 1138, 1068, 1026.

( \pm )-(4-Methoxyphenyl)(5,6,7-trimethoxyisoquinolin-1-yl)methanol (3e). This compound was prepared following general procedure A fom 5,6,7-trimethoxyisoquinoline (1b, $0.219 \mathrm{~g}$, $1.00 \mathrm{mmol})$ with TMPMgCl$\cdot \mathrm{LiCl}(1.0 \mathrm{M}$ in THF/toluene; $1.5 \mathrm{~mL}, 1.50 \mathrm{mmol}$ ) and 4-methoxybenzaldehyde (2a, $0.204 \mathrm{~g}$, $1.50 \mathrm{mmol}$ ). The crude residue was purified by flash column chromatography (ethyl acetate/iso-hexane $=1: 1$ ) to give $3 \mathrm{e}$ $(0.100 \mathrm{~g}, 28 \%)$ as a pale orange amorphous solid. ${ }^{1} \mathrm{H}$ NMR $\left(500 \mathrm{MHz}, \mathrm{CDCl}_{3}\right): \delta(\mathrm{ppm})=8.42(\mathrm{~d}, J=5.8 \mathrm{~Hz}, 1 \mathrm{H}), 7.85(\mathrm{~d}$, $J=5.8 \mathrm{~Hz}, 1 \mathrm{H}), 7.25(\mathrm{~d}, J=8.8 \mathrm{~Hz}, 2 \mathrm{H}), 6.91(\mathrm{~s}, 1 \mathrm{H}), 6.83(\mathrm{~d}, J=$ $8.8 \mathrm{~Hz}, 2 \mathrm{H}), 6.34(\mathrm{br} \mathrm{s}, 1 \mathrm{H}), 6.14(\mathrm{~s}, 1 \mathrm{H}), 4.02(\mathrm{~s}, 3 \mathrm{H}), 3.96$ $(\mathrm{s}, 3 \mathrm{H}), 3.79(\mathrm{~s}, 3 \mathrm{H}), 3.75(\mathrm{~s}, 3 \mathrm{H}) ;{ }^{13} \mathrm{C} \mathrm{NMR}\left(126 \mathrm{MHz}, \mathrm{CDCl}_{3}\right): \delta$ $(\mathrm{ppm})=159.3,157.0,153.6,147.2,143.9,138.5,135.9$, 129.1 (2C), 128.9, 122.2, 115.1, 114.3 (2C), 99.7, 72.5, 61.7, 61.3, 56.0, 55.4; HRMS (EI): $m / z(\%)=355.1407$ (calcd for $\mathrm{C}_{20} \mathrm{H}_{21} \mathrm{NO}_{5}$ : 355.1420); IR ( NaCl film): $\nu\left(\mathrm{cm}^{-1}\right)=2938,2835$, 1611, 1588, 1510, 1490, 1476, 1396, 1251, 1122, 1061, 1035, $962,833$.

( \pm )-(7-(Benzyloxy)-6-methoxyisoquinolin-1-yl)(4-(benzyloxy)phenyl)methanol (3f). This compound was prepared following general procedure A fom 7-(benzyloxy)-6-methoxyisoquinoline (1c, $0.265 \mathrm{~g}, 1.00 \mathrm{mmol})$ with TMPMgCl.LiCl $(1.0 \mathrm{M}$ in THF/toluene; $1.5 \mathrm{~mL}, 1.50 \mathrm{mmol}$ ) and 4-(benzyloxy)benzaldehyde (2e, $0.318 \mathrm{~g}, 1.50 \mathrm{mmol}$ ). The crude residue was purified by flash column chromatography (ethyl acetate/iso-hexane $=2: 1+2 \%$ triethylamine $)$ to give $3 \mathbf{f}(0.233 \mathrm{~g}, 49 \%)$ as a pale yellow solid. mp 107-109 ${ }^{\circ} \mathrm{C} ;{ }^{1} \mathrm{H}$ NMR (500 $\mathrm{MHz}, \mathrm{CD}_{2} \mathrm{Cl}_{2}$ ): $\delta$ $(\mathrm{ppm})=8.38(\mathrm{~d}, J=5.6 \mathrm{~Hz}, 1 \mathrm{H}), 7.53(\mathrm{~d}, J=5.6 \mathrm{~Hz}, 1 \mathrm{H})$, 7.41-7.38 (m, 6H), 7.38-7.34 (m, 3H), 7.30 (m, 1H), 7.18-7.14 $(\mathrm{m}, 3 \mathrm{H}), 7.13(\mathrm{~s}, 1 \mathrm{H}), 6.86(\mathrm{~d}, J=8.5 \mathrm{~Hz}, 2 \mathrm{H}), 6.14(\mathrm{~d}, J=5.6$ $\mathrm{Hz}, 1 \mathrm{H}), 6.04$ (d, $J=5.6 \mathrm{~Hz}, 1 \mathrm{H}), 5.05$ (d, $J=11.8 \mathrm{~Hz}, 1 \mathrm{H}), 5.01$ (s, 2H), $4.95(\mathrm{~d}, J=11.8 \mathrm{~Hz}, 1 \mathrm{H}), 3.96(\mathrm{~s}, 3 \mathrm{H}) ;{ }^{13} \mathrm{C} \mathrm{NMR}$ $\left(126 \mathrm{MHz}, \mathrm{CD}_{2} \mathrm{Cl}_{2}\right): \delta(\mathrm{ppm})=158.9,157.5,153.7,149.6,139.5$, 137.6, 136.9, 136.7, 134.2, 129.3 (2C), 129.2 (2C), 129.0 (2C), 128.8, 128.5, 128.2 (2C), 128.0 (2C), 121.2, 120.2, 115.5 (2C), 106.0, 105.5, 72.5, 71.3, 70.5, 56.5; HRMS (EI): $\mathrm{m} / \mathrm{z}(\%)=$ 477.1943 (calcd for $\mathrm{C}_{31} \mathrm{H}_{27} \mathrm{NO}_{4}$ : 477.1940); IR ( $\mathrm{KBr}$ pellet): $\nu\left(\mathrm{cm}^{-1}\right)=3403,3034,2932,1606,1509,1275,1237,1162$, 1056, 1009, 743, 695.

(6,7-Dimethoxyisoquinolin-1-yl)(3,4-dimethoxyphenyl)methanone (4, Papaveraldine). This compound was prepared following general procedure B from $3 \mathbf{b}(0.129 \mathrm{mg}, 0.330 \mathrm{mmol})$ with manganese(rv) oxide $(0.287 \mathrm{~g}, 3.30 \mathrm{mmol})$. The crude residue was purified by flash column chromatography (ethyl acetate/ dichloromethane $=2: 1+2 \%$ triethylamine) to give $4(0.080 \mathrm{~g}$, $68 \%)$ as a white solid. mp $206-208{ }^{\circ} \mathrm{C} ;{ }^{1} \mathrm{H}$ NMR $(500 \mathrm{MHz}$, $\left.\mathrm{CDCl}_{3}\right): \delta(\mathrm{ppm})=8.45(\mathrm{~d}, J=5.5 \mathrm{~Hz}, 1 \mathrm{H}), 7.70(\mathrm{~d}, J=1.9 \mathrm{~Hz}$, $1 \mathrm{H}), 7.64(\mathrm{~d}, J=5.5 \mathrm{~Hz}, 1 \mathrm{H}), 7.54(\mathrm{~s}, 1 \mathrm{H}), 7.42(\mathrm{dd}, J=8.4,1.9$ $\mathrm{Hz}, 1 \mathrm{H}), 7.14(\mathrm{~s}, 1 \mathrm{H}), 6.86(\mathrm{~d}, J=8.4 \mathrm{~Hz}, 1 \mathrm{H}), 4.05(\mathrm{~s}, 3 \mathrm{H}), 3.95$ $(\mathrm{s}, 6 \mathrm{H}), 3.94(\mathrm{~s}, 3 \mathrm{H}) ;{ }^{13} \mathrm{C} \mathrm{NMR}\left(126 \mathrm{MHz}, \mathrm{CDCl}_{3}: \delta(\mathrm{ppm})=\right.$ $194.1,154.0$, 153.0, 153.3, 151.2, 149.2, 140.2, 134.1, 130.1, 127.0, 123.0, 121.4, 112.1, 110.1, 105.0, 104.2, 56.3, 56.3, 56.2, 56.2; HRMS (EI): $m / z(\%)=353.1292$ (calcd for $\mathrm{C}_{20} \mathrm{H}_{19} \mathrm{NO}_{5}$ : 353.1263); IR (KBr pellet): $\nu\left(\mathrm{cm}^{-1}\right)=3424,3007,2970,2933$, 1656, 1593, 1582, 1504, 1460, 1433, 1270, 1229, 1140, 1025, $860,749$.

(4-Methoxyphenyl)(5,6,7-trimethoxyisoquinolin-1-yl)methanone (5, Thalimicrinone). This compound was prepared following general procedure B from 3 e $(0.060 \mathrm{~g}, 0.170 \mathrm{mmol})$ with manganese(Iv) oxide $(0.148 \mathrm{~g}, 1.70 \mathrm{mmol})$. The crude residue was purified by flash column chromatography (ethyl acetate/iso-hexane $=3: 2)$ to give $5(0.059 \mathrm{~g}, 98 \%)$ as a pale yellow solid. mp 151-153 ${ }^{\circ} \mathrm{C} ;{ }^{1} \mathrm{H}$ NMR (500 $\mathrm{MHz}, \mathrm{CDCl}_{3}$ ): $\delta$ $(\mathrm{ppm})=8.48(\mathrm{~d}, J=5.6 \mathrm{~Hz}, 1 \mathrm{H}), 7.98(\mathrm{~d}, J=5.6 \mathrm{~Hz}, 1 \mathrm{H}), 7.95$ (d, $J=8.9 \mathrm{~Hz}, 2 \mathrm{H}), 7.36(\mathrm{~s}, 1 \mathrm{H}), 6.96(\mathrm{~d}, J=8.9 \mathrm{~Hz}, 2 \mathrm{H}), 4.08$ (s, $3 \mathrm{H}), 4.03$ (s, 3H), 3.93 (s, 3H), 3.88 (s, 3H); ${ }^{13} \mathrm{C}$ NMR (126 MHz, $\left.\mathrm{CDCl}_{3}\right): \delta(\mathrm{ppm})=194.0,164.2,154.7,154.2,146.9,144.4$, 139.7, 133.4 (2C), 129.9, 129.3, 124.0, 116.7, 113.9 (2C), 100.5, 61.8, 61.4, 56.3, 55.7; HRMS (EI): $m / z(\%)=353.1264$ (calcd for $\mathrm{C}_{20} \mathrm{H}_{19} \mathrm{NO}_{5}$ : 353.1263); IR (KBr pellet): $\nu\left(\mathrm{cm}^{-1}\right)=2944,1651$, 1601, 1479, 1280, 1256, 1163, 1127, 1028, 934, 832.

(士)-1-[(3,4-Dimethoxyphenyl)(methoxy)methyl]-6,7-dimethoxyisoquinoline (6a, racemic Setigerine). This compound was prepared following general procedure $\mathrm{C}$ using sodium hydride (60\% in mineral oil; $0.014 \mathrm{~g}, 0.350 \mathrm{mmol})$ in dry DMF $(2 \mathrm{~mL})$, $3 \mathbf{b}(0.088 \mathrm{~g}, 0.230 \mathrm{mmol})$ in dry DMF $(2 \mathrm{~mL})$ and iodomethane $(0.040 \mathrm{~mL}, 0.690 \mathrm{mmol})$. The crude residue was purified by flash column chromatography (dichloromethane $/$ methanol = $95: 5)$ to give $6 \mathbf{a}(0.065 \mathrm{~g}, 77 \%)$ as a pale yellow solid. mp 145-147 ${ }^{\circ} \mathrm{C} ;{ }^{1} \mathrm{H}$ NMR $\left(500 \mathrm{MHz}, \mathrm{CDCl}_{3}\right): \delta(\mathrm{ppm})=8.41(\mathrm{~d}, J=$ $5.6 \mathrm{~Hz}, 1 \mathrm{H}), 7.71(\mathrm{~s}, 1 \mathrm{H}), 7.47$ (d, $J=5.6 \mathrm{~Hz}, 1 \mathrm{H}), 7.05$ (d, $J=1.9$ $\mathrm{Hz}, 1 \mathrm{H}), 7.04(\mathrm{~s}, 1 \mathrm{H}), 6.95(\mathrm{dd}, J=8.3,1.9 \mathrm{~Hz}, 1 \mathrm{H}), 6.76(\mathrm{~d}, J=$ $8.3 \mathrm{~Hz}, 1 \mathrm{H}), 5.85$ (s, 1H), 3.98 (s, 3H), 3.87 (s, 3H), $3.81(\mathrm{~s}, 3 \mathrm{H})$, 
$3.79(\mathrm{~s}, 3 \mathrm{H}), 3.46(\mathrm{~s}, 3 \mathrm{H}) ;{ }^{13} \mathrm{C} \mathrm{NMR}\left(126 \mathrm{MHz}, \mathrm{CDCl}_{3}: \delta(\mathrm{ppm})=\right.$ 157.2 , 152.5, 149.6, 149.0, 148.3, 140.7, 134.2, 133.6, 122.1, $119.8,118.7,110.8,109.7,105.2,104.5,87.2,57.5,56.1,56.0$ (3C); HRMS (EI): $m / z(\%)=369.1575$ (calcd for $\mathrm{C}_{21} \mathrm{H}_{23} \mathrm{NO}_{5}$ : 369.1576); IR (KBr pellet): $\nu\left(\mathrm{cm}^{-1}\right)=3439,2933,1512,1476$, 1461, 1428, 1269, 1249, 1225, 1155, 1140, 1108, 1049, 1026, 855.

( \pm )-1-[Benzo[d][1,3]dioxol-5-yl(methoxy)methyl]-6,7-dimethoxyisoquinoline (6b, racemic Setigeridine). This compound was prepared following general procedure $\mathrm{C}$ using sodium hydride (60\% in mineral oil; $0.009 \mathrm{~g}, 0.230 \mathrm{mmol})$ in dry DMF (1 mL), $3 \mathrm{c}(0.050 \mathrm{~g}, 0.150 \mathrm{mmol})$ in dry DMF $(1 \mathrm{~mL})$ and iodomethane $(0.030 \mathrm{~mL}, 0.450 \mathrm{mmol})$. The crude residue was purified by flash column chromatography (ethyl acetate/iso-hexane $=3: 1$ ) to give $6 \mathbf{b}(0.048 \mathrm{~g}, 91 \%)$ as a brown amorphous solid. ${ }^{1} \mathrm{H}$ NMR $\left(500 \mathrm{MHz}, \mathrm{CDCl}_{3}\right): \delta(\mathrm{ppm})=8.39(\mathrm{~d}, J=5.6 \mathrm{~Hz}, 1 \mathrm{H}), 7.69$ $(\mathrm{s}, 1 \mathrm{H}), 7.46(\mathrm{~d}, J=5.6 \mathrm{~Hz}, 1 \mathrm{H}), 7.03(\mathrm{~s}, 1 \mathrm{H}), 6.94(\mathrm{~d}, J=8.1 \mathrm{~Hz}$, $1 \mathrm{H}), 6.92(\mathrm{~s}, 1 \mathrm{H}), 6.71(\mathrm{~d}, J=8.1 \mathrm{~Hz}, 1 \mathrm{H}), 5.87(\mathrm{~d}, J=2.0 \mathrm{~Hz}$, $2 \mathrm{H}), 5.81(\mathrm{~s}, 1 \mathrm{H}), 3.98(\mathrm{~s}, 3 \mathrm{H}), 3.87(\mathrm{~s}, 3 \mathrm{H}), 3.45(\mathrm{~s}, 3 \mathrm{H}) ;{ }^{13} \mathrm{C}$ NMR $\left(126 \mathrm{MHz}, \mathrm{CDCl}_{3}\right): \delta(\mathrm{ppm})=157.1,152.5,149.6,147.7$, $146.8,140.7$, 135.0, 134.1, 122.1, 119.8, 119.7, 108.0, 107.2, 105.2, 104.5, 101.0, 87.3, 57.5, 56.0 (2C); HRMS (EI): $m / z(\%)=$ 353.1265 (calcd for $\mathrm{C}_{20} \mathrm{H}_{19} \mathrm{NO}_{5}$ : 353.1263); IR (KBr pellet): $\nu$ $\left(\mathrm{cm}^{-1}\right)=2935,1829,1621,1567,1504,1487,1435,1418,1252$, 1202, 1160, 1101, 1039.

(士)-7-(Benzyloxy)-1-[(4-(benzyloxy)phenyl)(methoxy)methyl]6-methoxyisoquinoline (6c). This compound was prepared following general procedure $\mathrm{C}$ using sodium hydride $(60 \%$ in mineral oil; $0.013 \mathrm{~g}, 0.320 \mathrm{mmol})$ in dry DMF (2 mL), 3f $(0.100 \mathrm{~g}, 0.220 \mathrm{mmol})$ in dry DMF $(2 \mathrm{~mL})$ and iodomethane $(0.040 \mathrm{~mL}, 0.630 \mathrm{mmol})$. The crude residue was purified by flash column chromatography (ethyl acetate) to give $\mathbf{6 c}$ $(0.093 \mathrm{~g}, 90 \%)$ as a yellow amorphous solid. ${ }^{1} \mathrm{H}$ NMR $\left(400 \mathrm{MHz}, \mathrm{CD}_{2} \mathrm{Cl}_{2}\right): \delta(\mathrm{ppm})=8.35(\mathrm{~d}, J=5.6 \mathrm{~Hz}, 1 \mathrm{H}), 7.88(\mathrm{~s}$, 1H), 7.51-7.46 (m, 3H), 7.43-7.29 (m, 10H), 7.10 (s, 1H), 6.88 (d, $J=8.8 \mathrm{~Hz}, 2 \mathrm{H}), 5.82(\mathrm{~s}, 1 \mathrm{H}), 5.15(\mathrm{~d}, J=11.9 \mathrm{~Hz}, 1 \mathrm{H}), 5.09$ $(\mathrm{d}, J=11.9 \mathrm{~Hz}, 1 \mathrm{H}), 5.02(\mathrm{~s}, 2 \mathrm{H}), 3.97(\mathrm{~s}, 3 \mathrm{H}), 3.38(\mathrm{~s}, 3 \mathrm{H}) ;{ }^{13} \mathrm{C}$ NMR (101 MHz, $\left.\mathrm{CD}_{2} \mathrm{Cl}_{2}\right)$ : $\delta(\mathrm{ppm})=158.5,157.9,153.4,149.2$, 141.1, 137.8, 137.1, 134.7, 134.1, 129.2 (2C), 129.0 (2C), 128.7, $128.4,128.3$ (2C), 128.1 (2C), 127.9 (2C), 122.4, 120.1, 115.0 (2C), 106.8, 105.9, 88.0, 71.1, 70.5, 57.6, 56.4; HRMS (EI): $m / z(\%)=491.2097$ (calcd for $\mathrm{C}_{32} \mathrm{H}_{29} \mathrm{NO}_{4}: 491.2097$ ); IR (NaCl film): $\nu\left(\mathrm{cm}^{-1}\right)=3032,2933,2824,1610,1566$, $1507,1477,1433$, 1380, 1250, 1226, 1171, 1158, 1098, 1049, 859, 750 .

1-[Hydroxy(4-hydroxyphenyl)methyl]-6-methoxyisoquinolin7-ol (7, Annocherin A). This compound was prepared following general procedure E from $3 \mathbf{f}(0.230 \mathrm{~g}, 0.480 \mathrm{mmol})$. Flash column chromatography (ethyl acetate/methanol/triethylamine $=96: 2: 2)$ afforded $7(0.128 \mathrm{~g}, 90 \%)$ as a yellow solid. $\mathrm{mp}$ 166-168 ${ }^{\circ} \mathrm{C} ;{ }^{1} \mathrm{H}$ NMR (400 MHz, MeOD): $\delta(\mathrm{ppm})=8.23(\mathrm{~d}, J=$ $5.7 \mathrm{~Hz}, 1 \mathrm{H}), 7.57$ (d, $J=5.7 \mathrm{~Hz}, 1 \mathrm{H}), 7.43$ (s, 1H), $7.22(\mathrm{~s}, 1 \mathrm{H})$, $7.18(\mathrm{~d}, J=8.6 \mathrm{~Hz}, 2 \mathrm{H}), 6.71(\mathrm{~d}, J=8.6 \mathrm{~Hz}, 2 \mathrm{H}), 6.19$ (s, 1H), $3.97(\mathrm{~s}, 3 \mathrm{H}) ;{ }^{13} \mathrm{C}$ NMR (101 MHz, MeOD): $\delta(\mathrm{ppm})=158.6$, $158.1,153.9,149.2,138.6,135.2,135.0,129.5$ (2C), 123.1, 121.2, 116.2 (2C), 108.6, 106.4, 74.8, 56.4; HRMS (EI): $m / z(\%)=$
297.0999 (calcd for $\mathrm{C}_{17} \mathrm{H}_{15} \mathrm{NO}_{4}$ : 297.1001); IR (KBr pellet): $\nu\left(\mathrm{cm}^{-1}\right)=3410,3180,2377,2297,1611,1514,1274,1229$, 1194, 1051, 977, 855, 842.

1-[(4-Hydroxyphenyl)(methoxy)methyl]-6-methoxyisoquinolin-7-ol (8, Annocherin B). This compound was prepared following general procedure E from 13 (0.080 g, $0.160 \mathrm{mmol})$. Flash column chromatography $($ dichloromethane $/$ methanol = 9:1) afforded $8(0.033 \mathrm{~g}, 66 \%)$ as a brown solid. $\mathrm{mp}$ 178-180 ${ }^{\circ} \mathrm{C} ;{ }^{1} \mathrm{H}$ NMR (400 MHz, MeOD): $\delta(\mathrm{ppm})=8.19(\mathrm{~d}, J=$ $5.7 \mathrm{~Hz}, 1 \mathrm{H}), 7.68(\mathrm{~s}, 1 \mathrm{H}), 7.56(\mathrm{~d}, J=5.7 \mathrm{~Hz}, 1 \mathrm{H}), 7.21-7.19(\mathrm{~m}$, $3 \mathrm{H}), 6.70(\mathrm{~d}, J=8.7 \mathrm{~Hz}, 2 \mathrm{H}), 5.81(\mathrm{~s}, 1 \mathrm{H}), 3.96(\mathrm{~s}, 3 \mathrm{H}), 3.38(\mathrm{~s}$, $3 \mathrm{H}) ;{ }^{13} \mathrm{C}$ NMR (101 MHz, MeOD): $\delta(\mathrm{ppm})=158.1,157.8$, 154.0, 149.2 , 139.2 , 135.3, 132.5, 129.3 (2C), 123.9, 121.4, 116.0 (2C), 108.9, 106.4, 86.4, 57.4, 56.4; HRMS (EI): $m / z(\%)=$ 311.1164 (calcd for $\mathrm{C}_{18} \mathrm{H}_{17} \mathrm{NO}_{4}$ : 311.1158); IR ( $\mathrm{NaCl}$ film): $\nu$ $\left(\mathrm{cm}^{-1}\right)=2923,1611,1594,1509,1479,1453,1431,1345,1259$, 1231, 1195, 1167, 1095, 856, 752.

1-(3,4-Dimethoxybenzyl)-6,7-dimethoxyisoquinoline

(9, Papaverine). This compound was prepared following general procedure D from $3 \mathbf{b}(0.100 \mathrm{~g}, 0.280 \mathrm{mmol})$ in $\mathrm{MeOH}(10 \mathrm{~mL})$, conc. $\mathrm{H}_{2} \mathrm{SO}_{4}(0.5 \mathrm{~mL})$ using $10 \% \mathrm{Pd} / \mathrm{C}(0.100 \mathrm{~g})$. The crude residue was purified by flash column chromatography (methyltert-butylether/ethyl acetate $=1: 1+5 \%$ triethylamine) to give 9 $(0.057 \mathrm{~g}, 60 \%)$ as a white solid. mp $145-147{ }^{\circ} \mathrm{C} ;{ }^{1} \mathrm{H}$ NMR $\left(400 \mathrm{MHz}, \mathrm{CDCl}_{3}\right): \delta(\mathrm{ppm})=8.36(\mathrm{~d}, J=5.6 \mathrm{~Hz}, 1 \mathrm{H}), 7.41(\mathrm{~d}, J$ $=5.6 \mathrm{~Hz}, 1 \mathrm{H}), 7.33(\mathrm{~s}, 1 \mathrm{H}), 7.03(\mathrm{~s}, 1 \mathrm{H}), 6.83-6.79(\mathrm{~m}, 2 \mathrm{H}), 6.75$ (d, $J=8.7 \mathrm{~Hz}, 1 \mathrm{H}), 4.52(\mathrm{~s}, 2 \mathrm{H}), 3.98(\mathrm{~s}, 3 \mathrm{H}), 3.89(\mathrm{~s}, 3 \mathrm{H}), 3.80$ $(\mathrm{s}, 3 \mathrm{H}), 3.75(\mathrm{~s}, 3 \mathrm{H}) ;{ }^{13} \mathrm{C}$ NMR $\left(101 \mathrm{MHz}, \mathrm{CDCl}_{3}\right): \delta(\mathrm{ppm})=$ 157.9, 152.5, 149.9, 149.1, 147.6, 141.2, 133.5, 132.4, 123.0, 120.6, 118.8, 112.0, 111.3, 105.4, 104.3, 56.1, 56.0, 55.9 (2C), 42.4; HRMS (ESI): $m / z(\%)=339.1471[\mathrm{M}+\mathrm{H}]^{+}$(calcd for $\mathrm{C}_{20} \mathrm{H}_{21} \mathrm{NO}_{4}$ : 339.1470); IR (KBr pellet): $\nu\left(\mathrm{cm}^{-1}\right)=2939,2835$, 1617,1589 , 1564, 1506, 1435, 1416, 1260, 1234, 1203, 1158, 1140, 1029, 985.

1-(3-Hydroxy-4-methoxybenzyl)-6,7-dimethoxyisoquinoline (10, Palaudine). This compound was prepared following general procedure D from 3d (0.070 g, $0.160 \mathrm{mmol})$ in $\mathrm{MeOH}(2 \mathrm{~mL})$, conc. $\mathrm{H}_{2} \mathrm{SO}_{4}(0.1 \mathrm{~mL})$ using $10 \% \mathrm{Pd} / \mathrm{C}(0.070 \mathrm{~g})$. The crude residue was purified by flash column chromatography (ethyl acetate) to give $10(0.039 \mathrm{~g}, 75 \%)$ as a white solid. mp $179-182{ }^{\circ} \mathrm{C} ;{ }^{1} \mathrm{H}$ NMR $\left(500 \mathrm{MHz}, \mathrm{CD}_{2} \mathrm{Cl}_{2}\right): \delta(\mathrm{ppm})=8.24(\mathrm{~d}, J=$ $5.7 \mathrm{~Hz}, 1 \mathrm{H}), 7.40(\mathrm{~d}, J=5.7 \mathrm{~Hz}, 1 \mathrm{H}), 7.31(\mathrm{~s}, 1 \mathrm{H}), 7.06(\mathrm{~s}, 1 \mathrm{H})$, 6.77-6.75 (m, 3H), $6.33(\mathrm{~s}, 1 \mathrm{H}), 4.45(\mathrm{~s}, 2 \mathrm{H}), 3.95(\mathrm{~s}, 3 \mathrm{H}), 3.86$ (s, 3H), $3.81(\mathrm{~s}, 3 \mathrm{H}) ;{ }^{13} \mathrm{C}$ NMR (101 MHz, $\left.\mathrm{CD}_{2} \mathrm{Cl}_{2}\right): \delta(\mathrm{ppm})=$ $158.4,153.2,150.6,146.5,145.9,141.2,133.9,133.6$, $123.3,120.4,119.1,115.4,111.4,105.8,104.7,56.5,56.4$, 56.3, 42.1; HRMS (EI): $\mathrm{m} / z \quad(\%)=325.1311$ (calcd for $\mathrm{C}_{19} \mathrm{H}_{19} \mathrm{NO}_{4}$ : 325.1314); IR (KBr pellet): $\nu\left(\mathrm{cm}^{-1}\right)=3439,2924$, 1620, 1586, 1569, 1508, 1480, 1434, 1422, 1277, 1234, 1203, 1161, 1133.

( \pm )-(2-Bromophenyl)(6,7-dimethoxyisoquinolin-1-yl)methanol (12a). This compound was prepared following general procedure A fom 6,7-dimethoxyisoquinoline (1a, $0.189 \mathrm{~g}$, $1.00 \mathrm{mmol})$ with TMPMgCl$\cdot \mathrm{LiCl}(1.0 \mathrm{M}$ in THF/toluene; $1.5 \mathrm{~mL}, 1.50 \mathrm{mmol}$ ) and 2-bromobenzaldehyde (11a, $0.278 \mathrm{~g}$, $1.50 \mathrm{mmol})$. The residue was purified by flash column chrom- 
atography (ethyl acetate/dichloromethane $=1: 1$ ) to give 12a (0.258 g, 69\%) as a white solid. mp 107-108 ${ }^{\circ} \mathrm{C} ;{ }^{1} \mathrm{H}$ NMR $\left(400 \mathrm{MHz}, \mathrm{CD}_{2} \mathrm{Cl}_{2}\right): \delta(\mathrm{ppm})=8.40(\mathrm{~d}, J=5.6 \mathrm{~Hz}, 1 \mathrm{H})$, $7.66-7.62(\mathrm{~m}, 1 \mathrm{H}), 7.56(\mathrm{~d}, J=5.6 \mathrm{~Hz}, 1 \mathrm{H}), 7.13-7.09(\mathrm{~m}, 3 \mathrm{H})$, 7.04 (s, 1H), 6.90-6.85 (m, 1H), $6.66(\mathrm{~s}, 1 \mathrm{H}), 3.94(\mathrm{~s}, 3 \mathrm{H}), 3.83$ $(\mathrm{s}, 3 \mathrm{H}) ;{ }^{13} \mathrm{C}$ NMR $\left(101 \mathrm{MHz}, \mathrm{CD}_{2} \mathrm{Cl}_{2}\right): \delta(\mathrm{ppm})=156.8,153.6$, $151.0,143.2$, 139.2, 134.1, 133.4, 130.2, 130.0, 128.7, 124.5, 121.4, 120.5, 105.8, 103.4, 71.6, 56.7, 56.5; HRMS (ESI): $m / z(\%)$ $=374.0389[\mathrm{M}+\mathrm{H}]^{+}$(calcd for $\mathrm{C}_{18} \mathrm{H}_{17} \mathrm{BrNO}_{3}$ : 373.0314$) ; \mathrm{IR}(\mathrm{KBr}$ pellet): $\nu\left(\mathrm{cm}^{-1}\right)=3509,3347,3057,2933,1623,1572,1510$, 1480, 1437, 1401, 1325, 1276, 1237, 1202, 1161, 1074, 1020, 974.

( \pm )-(2-Bromo-4,5-dimethoxyphenyl)(6,7-dimethoxyisoquinolin-1-yl)methanol (12b). This compound was prepared following general procedure A fom 6,7-dimethoxyisoquinoline (1a, $0.189 \mathrm{~g}, 1.00 \mathrm{mmol})$ with $\mathrm{TMPMgCl} \cdot \mathrm{LiCl}(1.0 \mathrm{M}$ in $\mathrm{THF} /$ toluene; $1.5 \mathrm{~mL}, 1.50 \mathrm{mmol}$ ) and 6-bromovertraldehyde (11b, $0.368 \mathrm{~g}, 1.50 \mathrm{mmol})$. The residue was purified by flash column chromatography (ethyl acetate/dichloromethane $=1: 2$ ) to give 12b $(0.152 \mathrm{~g}, 35 \%)$ as a white solid. mp $185-186{ }^{\circ} \mathrm{C} ;{ }^{1} \mathrm{H}$ NMR $\left(400 \mathrm{MHz}, \mathrm{CD}_{2} \mathrm{Cl}_{2}\right): \delta(\mathrm{ppm})=8.39(\mathrm{~d}, J=5.6 \mathrm{~Hz}, 1 \mathrm{H}), 7.55(\mathrm{~d}$, $J=5.6 \mathrm{~Hz}, 1 \mathrm{H}), 7.13(\mathrm{~s}, 1 \mathrm{H}), 7.09(\mathrm{~s}, 1 \mathrm{H}), 7.06(\mathrm{~s}, 1 \mathrm{H}), 6.56(\mathrm{~s}$, $1 \mathrm{H}), 6.35(\mathrm{~s}, 1 \mathrm{H}), 6.29(\mathrm{~s}, 1 \mathrm{H}), 3.94(\mathrm{~s}, 3 \mathrm{H}), 3.88(\mathrm{~s}, 3 \mathrm{H}), 3.80(\mathrm{~s}$, $3 \mathrm{H}), 3.49(\mathrm{~s}, 3 \mathrm{H}) ;{ }^{13} \mathrm{C} \mathrm{NMR}\left(101 \mathrm{MHz}, \mathrm{CD}_{2} \mathrm{Cl}_{2}\right): \delta(\mathrm{ppm})=$ $157.1,153.6$, 151.0, 150.2, 149.9, 139.2, 135.1, 134.0, 121.4, 120.4, 115.6, 114.3, 112.2, 105.8, 103.6, 71.5, 56.8, 56.6, 56.4, 56.2; HRMS (ESI): $m / z(\%)=433.0507$ (calcd for $\mathrm{C}_{20} \mathrm{H}_{20} \mathrm{BrNO}_{5}$ : 433.0525); IR (KBr pellet): $\nu\left(\mathrm{cm}^{-1}\right)=3293,2937,1619,1597$, 1570, 1508, 1434, 1405, 1271, 1254, 1235, 1200, 1155, 1030, 858.

1,2-Dimethoxy-7H-dibenzo[de,g]quinolin-7-one (13, Lysicamine). This compound was prepared following general procedure $\mathrm{F}$ from $12 \mathrm{a}(0.112 \mathrm{~g}, 0.300 \mathrm{mmol})$ to give $13(0.051 \mathrm{~g}$, $53 \%)$ as a yellow solid. mp $181-183{ }^{\circ} \mathrm{C} ;{ }^{1} \mathrm{H}$ NMR $(400 \mathrm{MHz}$, $\left.\mathrm{CD}_{2} \mathrm{Cl}_{2}\right): \delta(\mathrm{ppm})=9.22(\mathrm{ddd}, J=8.4,1.1,0.5,1 \mathrm{H}), 8.87(\mathrm{~d}, J=$ $5.2 \mathrm{~Hz}, 1 \mathrm{H}$ ), 8.50 (ddd, $J=7.9,1.7,0.5 \mathrm{~Hz}, 1 \mathrm{H}$ ), 7.85 (d, $J=5.2$ $\mathrm{Hz}, 1 \mathrm{H}), 7.79$ (ddd, $J=8.4,7.2,1.7 \mathrm{~Hz}, 1 \mathrm{H}), 7.60$ (ddd, $J=7.9$, 7.2, $1.1 \mathrm{~Hz}, 1 \mathrm{H}), 7.29(\mathrm{~s}, 1 \mathrm{H}), 4.09(\mathrm{~s}, 3 \mathrm{H}), 4.03(\mathrm{~s}, 3 \mathrm{H}) ;{ }^{13} \mathrm{C}$ NMR (101 MHz, $\left.\mathrm{CD}_{2} \mathrm{Cl}_{2}\right): \delta(\mathrm{ppm})=183.0,157.5,152.8,146.0$, $145.5,136.1,135.1,134.8,132.8,129.2,129.1,128.9,124.1$, 122.8, 120.1, 107.2, 61.1, 56.8; HRMS (EI): $m / z(\%)=291.0888$ (calcd for $\mathrm{C}_{18} \mathrm{H}_{13} \mathrm{NO}_{3}$ : 291.0895); IR (KBr pellet): $\nu\left(\mathrm{cm}^{-1}\right)=$ 1671, 1607, 1596, 1486, 1460, 1408, 1304, 1260, 1240, 1137, 1042, 1003, 933, 869.

1,2,9,10-Tetramethoxy-7H-dibenzo[de,g]quinolin-7-one $\quad(14$, Oxoglaucine). This compound was prepared following general procedure $\mathrm{F}$ from $12 \mathrm{~b}(0.130 \mathrm{~g}, 0.300 \mathrm{mmol})$ to give 14 $(0.062 \mathrm{~g}, 59 \%)$ as a dark orange solid. mp $212-214{ }^{\circ} \mathrm{C} ;{ }^{1} \mathrm{H}$ NMR $\left(400 \mathrm{MHz}, \mathrm{CD}_{2} \mathrm{Cl}_{2}\right): \delta(\mathrm{ppm})=8.81(\mathrm{~d}, J=5.2 \mathrm{~Hz}, 1 \mathrm{H}), 8.77(\mathrm{~s}$, $1 \mathrm{H}), 7.90(\mathrm{~s}, 1 \mathrm{H}), 7.77(\mathrm{~d}, J=5.2 \mathrm{~Hz}, 1 \mathrm{H}), 7.19(\mathrm{~s}, 1 \mathrm{H}), 4.07$ (s, $3 \mathrm{H}), 4.04$ (s, 3H), 4.02 (s, 3H), 4.01 (s, 3H); ${ }^{13} \mathrm{C}$ NMR (101 MHz, $\left.\mathrm{CD}_{2} \mathrm{Cl}_{2}\right): \delta(\mathrm{ppm})=181.7,157.3,154.4,151.7,150.2,146.1$, $145.2,135.9,129.7,127.4,123.8,122.2,120.2$, 110.9, 109.9, 106.7, 61.0, 56.7, 56.5, 56.4; HRMS (EI): $m / z(\%)=351.1102$ (calcd for $\mathrm{C}_{20} \mathrm{H}_{17} \mathrm{NO}_{5}$ : 351.1107); IR (KBr pellet): $\nu\left(\mathrm{cm}^{-1}\right)=$ 1646, 1593, 1571, 1510, 1462, 1424, 1412, 1360, 1301, 1274, 1240, 1143, 1067, 1001, 883.

\section{References}

1 J. M. Hagel and P. J. Facchini, Plant Cell Physiol., 2013, 54, 547.

2 M. Shamma, The isoquinoline alkaloids: chemistry and pharmacology, Academic Press, 1972.

3 J. R. Kershaw and B. C. Uff, Chem. Commun., 1966, 331.

4 H.-Y. Cheng and R. W. Doskotch, J. Nat. Prod., 1980, 43, 151.

5 S. Al-Khalil and P. L. Schiff Jr., J. Nat. Prod., 1985, 48, 989.

6 J. Jacobs, N. van Tuyen, P. Markusse, C. V. Stevens, L. Maat and N. De Kimpe, Tetrahedron, 2009, 63, 1188.

7 E. Awuah and A. Capretta, J. Org. Chem., 2010, 75, 5627.

8 R. Shankar, S. S. More, M. V. Madhubabu, N. Vembu and U. K. Syam Kumar, Synlett, 2012, 1013.

9 M. V. Madhubabu, R. Shankar, R. Akula, U. K. Syam Kumar and M. V. Basaveswara Rao, Der Pharma Chemica, 2014, 6, 50.

10 A. J. Birch, A. H. Jackson and P. V. R. Shannon, J. Chem. Soc., Perkin Trans. 1, 1974, 2190.

11 K. Kido and Y. Watanabe, Heterocycles, 1980, 14, 1151.

12 K. Matcha and A. P. Antonchick, Angew. Chem., Int. Ed., 2013, 52, 2082.

13 Y. Siddaraju, M. Lamani and K. R. Prabhu, J. Org. Chem., 2014, 79, 3856.

14 T.-H. Chuang, C.-F. Li, H.-Z. Lee and Y.-C. Wen, J. Org. Chem., 2013, 78, 4974.

15 A. Krasovskiy, V. Malakhov, A. Gavryushin and P. Knochel, Angew. Chem., Int. Ed., 2006, 45, 6040. This protocol could not be applied to 2-bromobenzoyl chloride, see ref. 14.

16 B. Melzer, A. Plodek and F. Bracher, J. Org. Chem., 2014, 79, 7239.

17 A. Plodek, M. König and F. Bracher, Eur. J. Org. Chem., 2015, 1302.

18 A. Krasovskiy, V. Krasovskaya and P. Knochel, Angew. Chem., Int. Ed., 2006, 45, 2958.

19 A. Metzger, M. A. Schade and P. Knochel, Org. Lett., 2008, 10, 1107.

20 S. M. Kupchan and P. F. O'Brien, J. Chem. Soc., Chem. Commun., 1973, 915.

21 L. Castedo, J. M. Saá, R. Suau and C. Viilaverde, Heterocycles, 1980, 14, 1131.

22 S. V. Kessar, Y. P. Gupta, V. S. Yadav, M. Narula and T. Mohammed, Tetrahedron Lett., 1980, 21, 3307.

23 K. Orito, S. Uchiito, Y. Satoh, T. Tatsuzawa, R. Harada and M. Tokuda, Org. Lett., 2000, 2, 307.

24 G. D. Cuny, Tetrahedron Lett., 2004, 45, 5167.

25 S. Chaudhary, S. Pecic, O. LeGendre and W. W. Harding, Tetrahedron Lett., 2009, 50, 2437.

26 C. Stévigny, C. Bailly and J. Quetin-Leclercq, Curr. Med. Chem.: Anti-Cancer Agents, 2005, 5, 173.

27 Y. Liu, J. Liu, D. Di, M. Li and Y. Fen, Curr. Top. Med. Chem., 2013, 13, 2116.

28 J.-L. Ferron and P. L'Ecuyer, Can. J. Chem., 1955, 33, 97.

29 L. Stuchlik, Monatsh. Chem., 1900, 21, 813. 
30 J. A. Weisbach, J. L. Kirkpatrick, E. Macko and B. Douglas, J. Med. Chem., 1968, 11, 760. The authors erroneously claimed 3a to be a natural product.

31 M. Jaric, B. A. Haag, A. Unsinn, K. Karaghiosoff and P. Knochel, Angew. Chem., Int. Ed., 2010, 49, 5451.

32 D. L. Boger, C. E. Brotherton and M. D. Kelley, Tetrahedron, 1981, 37, 3977.

33 T. R. Suess and F. R. Stermitz, J. Nat. Prod., 1981, 44, 688.

34 E. Reimann and H. Renz, Arch. Pharm., 1993, 326, 253.

35 G. Goldschmiedt, Monatsh. Chem., 1885, 6, 954.

36 K. H. C. Baser, J. Nat. Prod., 1982, 45, 704.

37 J. Slavik and L. Slavikova, Collect. Czech. Chem. Commun., 1996, 61, 1047.

38 S. Mahboobi, H. Pongratz and W. Wiegrebe, Pharmazie, 1997, 52, 399.
39 C.-Y. Chen, F.-R. Chang, W.-B. Pan and Y.-C. Wu, Phytochemistry, 2001, 56, 753.

40 A. Pictet and A. Gams, Ber. Dtsch. Chem. Ges., 1909, 42, 2943.

41 E. Brochmann-Hanssen and K. Hirai, J. Pharm. Sci., 1968, 57, 940 .

42 A. Brossi and S. Teitel, J. Org. Chem., 1970, 35, 1684.

43 N. Katsui, K. Sato, S. Tobinaga and N. Takeuchi, Tetrahedron Lett., 1966, 50, 6257.

44 M. Tomita, Y. Tsang-Hsiung, H. Furukawa and Y. Hui-Mei, Yakugaku Zasshi, 1962, 82, 1574.

45 M. A. Buchanan and E. E. Dickey, J. Org. Chem., 1960, 25, 1389.

46 J. Cohen, W. von Rosenthal and W. I. Taylor, J. Org. Chem., 1961, 26, 4143. 